\title{
First-principle insights into the catalytic role of indium oxide in methanol steam reforming
}

\author{
Sen Lin *, Xinxin Ye \\ Research Institute of Photocatalysis, Fujian Provincial Key Laboratory of Photocatalysis, State Key Laboratory Breeding Base, Fuzhou University, \\ Fuzhou 350002, Fujian, China
}

\section{A R T I C L E I N F O}

Article history:

Received 4 June 2013

Accepted 10 July 2013

Published 20 October 2013

Keywords:

Density functional theory

Methanol steam reforming

Reaction mechanism

Indium oxide

\begin{abstract}
A B S T R A C T
Using first-principle methods, we have shown that formaldehyde can be selectively converted to $\mathrm{CO}_{2}$ over $\mathrm{In}_{2} \mathrm{O}_{3}(110)$. The $\mathrm{OH}$ generated from the splitting of water was found to assist in the dehydrogenation of formaldehyde to give the corresponding formyl (CHO) species. Rather than direct dehydrogenation, a hydrogen atom from the $\mathrm{CHO}$ was then removed by a neighboring $\mathrm{OH}$ to produce CO. Finally, in favoring of desorption, the $\mathrm{CO}$ seized a lattice $\mathrm{O}$ atom to yield $\mathrm{CO}_{2}$. Our calculation results indicate that $\mathrm{In}_{2} \mathrm{O}_{3}$ plays an important role in terms of selectivity during the methanol steam reforming reaction without the participation of the PdIn alloy, confirming the experimentally observed selectivity towards $\mathrm{CO}_{2}$.
\end{abstract}

(C) 2013, Dalian Institute of Chemical Physics, Chinese Academy of Sciences. Published by Elsevier B.V. All rights reserved.

\section{Introduction}

Although hydrogen based proton exchange membrane (PEM) fuel cells represent an efficient and environmentally friendly solution to the growing transportation and mobile power needs of the world, their application in this regard have been limited partly because of the problem associated with the storage and transportation of hydrogen. Fortunately, methanol steam reforming (MSR) provides an effective solution to this problem for the generation of hydrogen [1,2], with the process occurring as follows:

$$
\mathrm{CH}_{3} \mathrm{OH}+\mathrm{H}_{2} \mathrm{O} \rightarrow 3 \mathrm{H}_{2}+\mathrm{CO}_{2}, \quad \Delta H^{0}=49.6 \mathrm{~kJ} / \mathrm{mol}
$$

There are several key advantages to an MSR-based solution, including: (1) the system derives hydrogen from a liquid fuel, which can be safely stored and transported; (2) the technology for the large scale production of methanol from other feedstocks is well established, with significant industrial capacity already in place; and (3) with its high $\mathrm{H} / \mathrm{C}$ ratio and the ab- sence of sulfur or nitrogen, MSR can be considered as a clean fuel [3].

A large number of mechanistic studies have been conducted on transition metal catalyzed MSR processes using metals such as $\mathrm{Cu}$ and $\mathrm{Pd}$ supported on $\mathrm{ZnO}$, because of the industrial importance of the MSR process [1,2,4-15]. Catalysts of this particular type have been shown to possess high levels of selectivity towards $\mathrm{CO}_{2}$ over $\mathrm{CO}$, which is important for potential fuel cell applications because the formation of a $\mathrm{CO}$ byproduct would otherwise poison the anodes of PEM fuel cells [1,2]. The synthesis of a new catalyst consisting Pd supported on $\mathrm{In}_{2} \mathrm{O}_{3}$ was recently reported by Iwasa et al. [5] who also found that the material exhibited extremely high levels of catalytic activity towards the MSR process. In a similar manner to $\mathrm{PdZn}$, the bimetallic PdIn alloy resulting from the heating of $\mathrm{Pd}$ and $\mathrm{In}_{2} \mathrm{O}_{3}$ under reductive conditions is believed to be beneficial for switching from CO-selective methanol dehydrogenation to $\mathrm{CO}_{2}$ selective MSR. A subsequent experiment revealed that the use

\footnotetext{
* Corresponding author. Tel: +86-591-83969175; Fax: +86-591-83779105; E-mail: slin@fzu.edu.cn

This work was supported by the National Natural Science Foundation of China (21203026), the Natural Science Foundation of Fujian Province, China (2012J05022), and the Specialized Research Fund for the Doctoral Program of Higher Education (20123514120001).

DOI: 10.1016/S1872-2067(12)60662-7 | http://www.sciencedirect.com/science/journal/18722067 | Chin. J. Catal., Vol. 34, No. 10, October 2013
} 
of $\mathrm{In}_{2} \mathrm{O}_{3}$ in isolation as a catalyst for the MSR reaction did not provide high levels of $\mathrm{CO}_{2}$ selectivity [16]. The behavior of pure $\mathrm{In}_{2} \mathrm{O}_{3}$ in the MSR reaction is therefore very similar to that of pure $\mathrm{ZnO}$, which provides similar levels of $\mathrm{CO}_{2}$ selectivity (95\%-99.6\%), albeit with low specific activity as well as an oxide component that has been speculated to enhance the selective conversion of formaldehyde-containing species $[17,18]$. Interestingly, the results of an experiment recently conducted by Bielz et al. [19] indicated that the use of formaldehyde as a reagent led to $95 \%$ selectivity towards $\mathrm{CO}_{2}$ on a pure $\mathrm{In}_{2} \mathrm{O}_{3}$ catalyst under typical steam reforming conditions. In contrast, Klötzer et al. [20] recently demonstrated that formaldehyde was only partially converted to $\mathrm{CO}_{2}$ using a PdIn phase, and that a high $\mathrm{CO}_{2}$ turnover frequency value could only be obtained when the reaction temperature was increased to at least $593 \mathrm{~K}$. Although these findings did not definitively confirm the role of $\mathrm{In}_{2} \mathrm{O}_{3}$ in the MSR process, they provided the suggestion that $\mathrm{In}_{2} \mathrm{O}_{3}$ plays a critical role in the transformation of formaldehyde to $\mathrm{CO}_{2}$. From a theoretical perspective, Ge et al. [21] reported that it was unlikely that the dehydrogenation of methanol to CO occurred on the PdIn(110) surface because of the high energy barriers.

To our best knowledge, very few theoretical studies have been published pertaining to the mechanistic aspects of this particular system because of the complex structure of $\operatorname{In}_{2} \mathrm{O}_{3}$ [22-26]. Lin et al. [22] recently reported that methanol and water could both be dehydrogenated to form formaldehyde and hydroxyl intermediates, respectively. Herein, to develop a better understand of the catalytic role of $\mathrm{In}_{2} \mathrm{O}_{3}$ in the MSR reaction, we have conducted for the first time a periodic density functional theory (DFT) study for the selective conversion of formaldehyde to $\mathrm{CO}_{2}$.

\section{Theory}

All of the calculations carried out in the current study were based on periodic DFT calculations using the Vienna ab initio simulation package (VASP) [27-29] with the gradient-corrected PW91 exchange-correction functional [30]. A plane-wave basis set was employed for the valence electrons with a cut-off of $500 \mathrm{eV}$, and the ionic cores were described according to the projector augmented-wave (PAW) method [31,32]. A $2 \times 2 \times 1$ Monkhorst-Pack $k$-point grid was adopted to sample the Brillouin zone, which was tested as being converged. The lattice parameter of $\mathrm{In}_{2} \mathrm{O}_{3}$ was calculated to be $10.328 \AA$, which was in good agreement with the previously reported results $[22,26]$. The $\mathrm{In}_{2} \mathrm{O}_{3}(110)$ surface was selected as a slab model, consisting of four atomic layers of a $1 \times 1$ unit cell with all eighty atoms in the top two layers being completely relaxed in all of the calculations. A vacuum spacing of $14 \AA$ was used to avoid any interactions between the adsorbates and the slab images in the $z$ direction.

The adsorption energy was calculated using the formula $E_{\text {ads }}$ $=E($ adsorbate + surface $)-E($ free molecule $)-E$ (free surface $)$. The climbing image nudged elastic band (CI-NEB) method [33] was used to determine the transition states with the conventional energy $\left(10^{-4} \mathrm{eV}\right)$ and force $(0.03 \mathrm{eV} / \AA ̊ \AA)$ convergence cri- teria. The highest image along the minimum energy path was denoted as the transition state. The energy barrier $E_{\mathrm{a}}$ of each elementary reaction was calculated from the energy difference between the transition state and the initial state. The reaction energy $\Delta E$ of each elementary reaction was calculated from the energy difference between the final state and the initial state.

\section{Results and discussion}

\subsection{Adsorption of pertinent species}

Among all of the known polymorphs of $\operatorname{In}_{2} \mathrm{O}_{3}$, the bodycentered cubic bixbyite crystal structure consisting of eighty atoms in one unit cell represents the most thermodynamically stable phase. Our calculated bulk parameters were found to be in agreement with those of the model used by Walsh et al. [23]. The (110) surface was generated from this stable crystal bulk as our slab model (See Ref. [22] for details).

Prior to exploring the reaction steps, it is necessary to develop a deeper understanding of the processes involved in the adsorption of the relevant species onto the $\mathrm{In}_{2} \mathrm{O}_{3}$ surface. Figure 1 defines all the sites investigated on the $\operatorname{In}_{2} \mathrm{O}_{3}$ surface. The adsorption energies and geometries of all of the relevant species are listed in Table 1 and Fig. 2. In general, the $O$ and $C$ atoms of these species favor interactions with the lattice In and $\mathrm{O}$ atoms, respectively.

\subsection{1. $\mathrm{A1}: \mathrm{CH}_{2} \mathrm{O}^{*}$}

As an important intermediate of MSR that is regularly observed in MSR experiments, this molecule was found to bind to the surface with its $\mathrm{O}$ and $\mathrm{C}$ atoms binding to the surface $\mathrm{In}_{1}$ and $\mathrm{O}_{1}$ atoms, respectively. The $\mathrm{C}-\mathrm{O}$ bond length in this particular case was determined to be about $0.18 \AA$ longer than the value observed in the isolated state of formaldehyde (1.21 $\AA$ ). The $\mathrm{C}-\mathrm{O}_{1}$ and $\mathrm{O}-\mathrm{In}_{1}$ distances were found to be 1.46 and $2.08 \AA$,

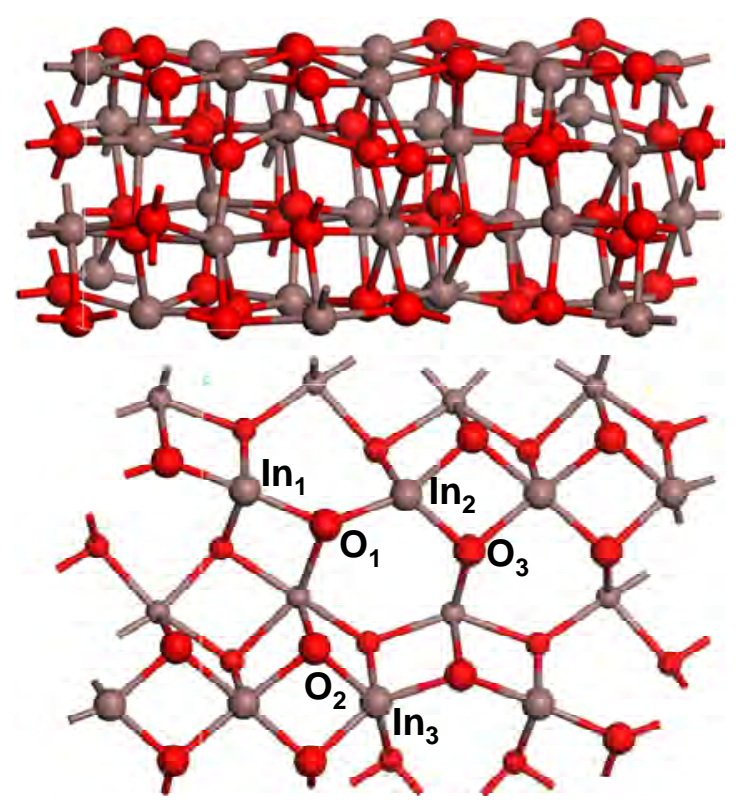

Fig. 1. Site map (top and side views) of the $\mathrm{In}_{2} \mathrm{O}_{3}(110)$ surface. The bottom two layers have been neglected and the atoms of first layer have been represented by larger balls in the top view. 
Table 1

Preferred adsorption sites, geometric parameters, and binding energies for the relevant species on $\operatorname{In}_{2} \mathrm{O}_{3}(110)$.

\begin{tabular}{|c|c|c|c|c|}
\hline \multirow{2}{*}{ Species } & \multirow{2}{*}{$\begin{array}{c}\text { Adsorption } \\
\text { configuration } \\
\end{array}$} & \multicolumn{2}{|c|}{ Bond details } & \multirow{2}{*}{$\begin{array}{l}\text { Adsorption } \\
\text { energy }(\mathrm{eV})\end{array}$} \\
\hline & & Bond & Length $(\AA)$ & \\
\hline \multirow[t]{5}{*}{$\mathrm{CH}_{2} \mathrm{O}^{*}$} & $\operatorname{In}_{1}-\mathrm{O}_{1}$ site through $\mathrm{O}$ and $\mathrm{C}$ & $\mathrm{C}-\mathrm{O}$ & 1.39 & -1.65 \\
\hline & & $\mathrm{C}-\mathrm{O}_{1}$ & 1.46 & \\
\hline & & $0-\operatorname{In}_{1}$ & 2.08 & \\
\hline & & $\mathrm{C}-\mathrm{H}_{1}$ & 1.11 & \\
\hline & & $\mathrm{C}-\mathrm{H}_{2}$ & 1.11 & \\
\hline \multirow[t]{4}{*}{$\mathrm{CHO}^{*}$} & $\mathrm{In}_{1}-\mathrm{O}_{1}$ site through $\mathrm{O}$ and $\mathrm{C}$ & $\mathrm{C}-\mathrm{O}$ & 1.27 & -3.91 \\
\hline & & $\mathrm{C}-\mathrm{O}_{1}$ & 1.28 & \\
\hline & & $0-\operatorname{In}_{1}$ & 2.22 & \\
\hline & & $\mathrm{C}-\mathrm{H}$ & 1.10 & \\
\hline $\mathrm{CO}^{*}$ in & $\mathrm{In}_{1}-\mathrm{O}_{1}$ site through $\mathrm{O}$ and $\mathrm{C}$ & $\mathrm{C}-\mathrm{O}$ & 1.25 & -0.85 \\
\hline \multirow[t]{2}{*}{$\mathrm{COO}_{\text {lattice }} *$} & & $\mathrm{C}-\mathrm{O}_{1}$ & 1.31 & \\
\hline & & $0-\operatorname{In}_{1}$ & 2.30 & \\
\hline $\mathrm{CO}^{*}$ in & $\mathrm{In}_{1}-\mathrm{O}_{1}$ site through $\mathrm{C}$ & $\mathrm{C}-\mathrm{O}$ & 1.21 & -1.36 \\
\hline $\mathrm{COO}_{\text {lattice }}{ }^{*}$ & & $\mathrm{C}-\mathrm{O}_{1}$ & 1.28 & \\
\hline (isomer) & & $0-\mathrm{In}_{1}$ & 2.35 & \\
\hline
\end{tabular}
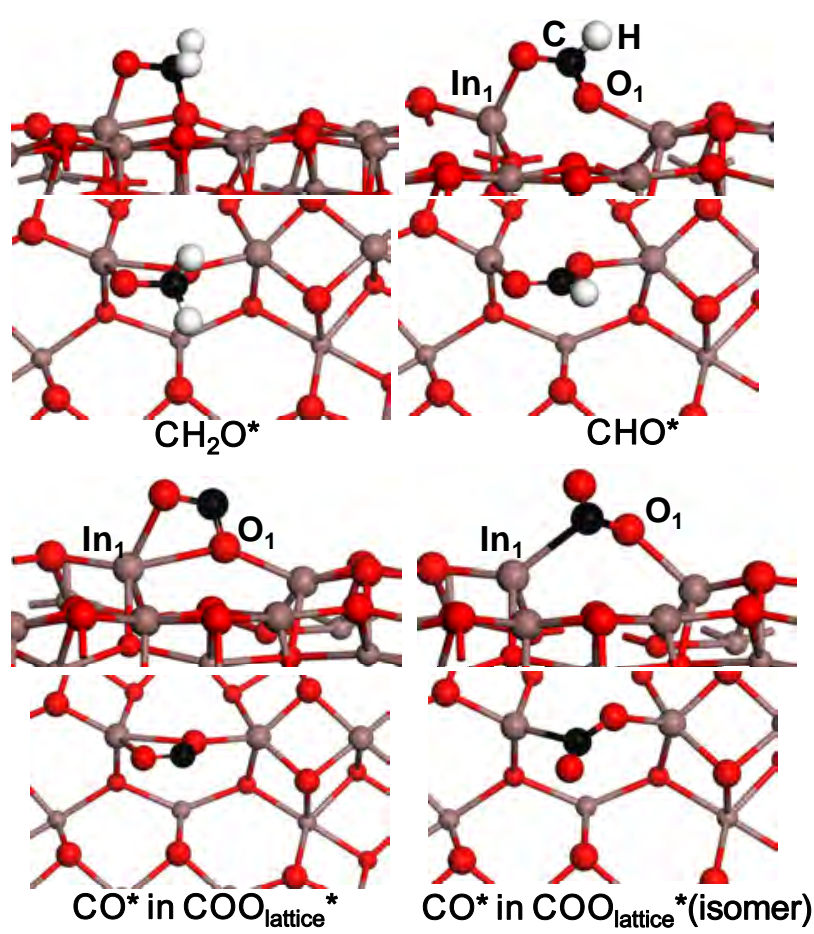

Fig. 2. Side and top views of the most stable adsorption configurations of the relevant species on $\mathrm{In}_{2} \mathrm{O}_{3}(110)$.

respectively. In contrast to the weak adsorption reported on the pure Pd $(-0.64 \mathrm{eV})[11]$ and PdIn surfaces $(-0.13 \mathrm{eV})$ [21] the adsorption energy of $\mathrm{CH}_{2} \mathrm{O}^{*}$ was calculated to be $-1.65 \mathrm{eV}$, indicating that it would be difficult for this species to be desorbed during the reactions.

\subsection{2. $A 2: \mathrm{CHO}^{*}$}

Formyl is a radical-like species that prefers to be adsorbed onto the $\mathrm{In}_{1}-\mathrm{O}_{1}$ bridge site with its $\mathrm{C}$ and $\mathrm{O}$ atoms forming bonds with the $\mathrm{O}_{1}$ and $\mathrm{In}_{1}$ atoms, respectively. After being adsorbed, the $\mathrm{In}_{1}-\mathrm{O}_{1}$ bond length was found to have increased from a value of 2.35 to $2.62 \AA$. The angles of the $\mathrm{O}-\mathrm{C}-\mathrm{O}_{1}$ and
C-O- $\mathrm{In}_{1}$ bonds were calculated to be about $121.18^{\circ}$ and $101.73^{\circ}$, respectively. In contrast to $\mathrm{CH}_{2} \mathrm{O}^{*}$, the $\mathrm{C}-\mathrm{O}_{1}$ bond length for $\mathrm{CHO}^{*}$ was much shorter $\left(1.28 \AA\right.$ ) , whereas the O- $\mathrm{In}_{1}$ distance was longer (2.22 $\AA$ ). Among all of the relevant reaction intermediates [22], the adsorption energy of $\mathrm{CHO}^{*}$ was the third lowest with the value of $-3.91 \mathrm{eV}$ (larger than $\mathrm{CH}_{2} \mathrm{OH}^{*}$ and $\mathrm{H}^{*}$ ), which was in accordance with its radical nature. Interestingly, $\mathrm{CHO}^{*}$ possesses a much greater adsorption energy $(-1.33 \mathrm{eV})$ on PdIn(110) [21], suggesting that the CHO* produced during the MSR reaction on $\mathrm{Pd} / \mathrm{In}_{2} \mathrm{O}_{3}$ may prefer to locate at the oxide sites of the substrate.

\subsubsection{A3: $\mathrm{CO}^{*}$ in $\mathrm{COO}_{\text {lattice }}{ }^{*}$}

Once $\mathrm{CHO}^{*}$ gives out its $\mathrm{H}$ atom, $\mathrm{CO}^{*}$ species form above the $\mathrm{In}_{1}-\mathrm{O}_{1}$ bridge site. The $\mathrm{C}$ atom of the $\mathrm{CO}^{*}$ then connects to the lattice $\mathrm{O}$ atom $\left(\mathrm{O}_{1}\right)$, generating a new product namely $\mathrm{COO}_{\text {lattice }}$. As shown in Fig. 2, this species behaves in a bidentate fashion because of its two 0 atoms, which can bot both bind with the surface In atoms. The CO portion lies almost parallel to the surface with a $\mathrm{C}-\mathrm{O}$ bond length of $1.25 \AA$. The $\mathrm{C}-\mathrm{O}_{1}$ and $\mathrm{O}-\mathrm{In}_{1}$ distances were calculated to be 1.31 and $2.30 \AA$, respectively. Furthermore, the $\mathrm{O}-\mathrm{C}-\mathrm{O}_{1}\left(117.34^{\circ}\right)$ and $\mathrm{C}-\mathrm{O}-\mathrm{In}_{1}\left(98.79^{\circ}\right)$ angles in this configuration had changed very little compared with those of the $\mathrm{CHO}^{*}$ species. The adsorption energy of $\mathrm{CO}^{*}$ was determined to be $-0.85 \mathrm{eV}$.

\subsubsection{A4: $\mathrm{CO}^{*}$ in $\mathrm{COO}_{\text {lattice }}$ (isomer)}

Based on our NEB calculation results, we discovered that an isomer of $\mathrm{COO}_{\text {lattice }}$ * existed along the reaction pathway of adsorbed $\mathrm{CO}_{2}{ }^{*}$ escaping from the surface to form $\mathrm{CO}_{2}$ gas. Although the adsorption pattern of this material was also bidentate, this isomer points its $\mathrm{O}$ atom away from the surface. In this configuration, the $\mathrm{C}-\mathrm{O}$ and $\mathrm{C}-\mathrm{O}_{1}$ bond lengths were found to be 1.21 and $1.28 \AA$, respectively, and the $\mathrm{O}-\mathrm{C}-\mathrm{O}_{1}$ and $\mathrm{O}-\mathrm{C}-\mathrm{In}_{1}$ bond angles were calculated to be $134.25^{\circ}$ and $118.41^{\circ}$, respectively. The binding energy for $\mathrm{CO}$ in this isomer was about $-0.51 \mathrm{eV}$ lower than that of A3.

\subsection{Reactions}

To study the mechanism for the methanol decomposition reaction on the $\mathrm{In}_{2} \mathrm{O}_{3}(110)$ surface, we calculated the activation energy barriers and exothermicities for all possible elemental steps. During all of the calculated reactions, $\mathrm{In}_{1}-\mathrm{O}_{1}$ was found to be a special active site. To the best of our knowledge, no theoretical studies of this reaction have been reported in the literature. The calculation results are listed in Table 2 , and the configurations of the initial state, transition state and final state are displayed in Fig. 3.

\subsection{1. $\mathrm{R} 1: \mathrm{CH}_{2} \mathrm{O}^{*} \rightarrow \mathrm{CHO}^{*}+\mathrm{H}^{*}$}

We started the reaction from $\mathrm{CH}_{2} \mathrm{O}^{*}$, which is considered to be an important intermediate during the MSR reaction. In the initial state, the reactant $\mathrm{CH}_{2} \mathrm{O}^{*}$ was located at its most stable $\mathrm{In}_{1}-\mathrm{O}_{1}$ bridge site with one $\mathrm{H}$ atom pointing towards a lattice $\mathrm{O}_{2}$ atom. In the transition state, the length of the breaking $\mathrm{C}-\mathrm{H}$ bond reached $1.32 \AA$, and the distance between the $\mathrm{H}$ atom and 
Table 2

Calculated activation and reaction energies for the elementary reactions on $\mathrm{In}_{2} \mathrm{O}_{3}(110)$ studied in this work.

\begin{tabular}{lccc}
\hline $\begin{array}{l}\text { Step } \\
\text { no. }\end{array}$ & Elementary reaction & $\begin{array}{c}\text { Activation } \\
\text { energy } E_{\mathrm{a}} \\
(\mathrm{eV})\end{array}$ & $\begin{array}{c}\text { Exothermicity } \\
\Delta E(\mathrm{eV})\end{array}$ \\
\hline $\mathrm{R} 1$ & $\mathrm{CH}_{2} \mathrm{O}^{*} \rightarrow \mathrm{CHO}^{*}+\mathrm{H}^{*}$ & 0.73 & -1.07 \\
$\mathrm{R} 2$ & $\mathrm{CH}_{2} \mathrm{O}^{*}+\mathrm{OH}^{*} \rightarrow \mathrm{CHO}^{*}+\mathrm{H}_{2} \mathrm{O}^{*}$ & 0.15 & -2.67 \\
$\mathrm{R} 3$ & $\mathrm{CHO}^{*} \rightarrow \mathrm{CO}^{*}+\mathrm{H}^{*}$ & 1.91 & 0.48 \\
$\mathrm{R} 4$ & $\mathrm{CHO}^{*}+\mathrm{OH}^{*} \rightarrow \mathrm{CO}^{*}+\mathrm{H}_{2} \mathrm{O}^{*}$ & 0.58 & 0.43 \\
$\mathrm{R} 5$ & $\mathrm{COO}_{\text {lattice }} \rightarrow \mathrm{COO}_{\text {lattice }}$ (isomer) & 0.20 & -0.51 \\
$\mathrm{R} 6$ & $\mathrm{COO}_{\text {lattice }}$ (isomer) $\rightarrow \mathrm{COO}_{\text {lattice }}$ (gas) & 0.23 & 0.17 \\
\hline
\end{tabular}

$\mathrm{O}_{2}$ atom was computed to be about $1.36 \AA$. At the same time, the three distances between the $\mathrm{O}_{2}$-In bonds increased to 2.48 , 2.21 , and 2.21 A. The product $\mathrm{CHO}^{*}$ was generated after the $\mathrm{O}_{2}$ atom received the hydrogen atom, with the material being subsequently located at the $\mathrm{In}_{1}-\mathrm{O}_{1}$ bridge site with the $\mathrm{C}$ and $\mathrm{O}$ atoms interacting with $\mathrm{O}_{1}$ and $\mathrm{In}_{1}$ atoms, respectively. In addition, the $\mathrm{H}$ atom of the $\mathrm{CHO}^{*}$ species was found to point away from the surface. Another $\mathrm{H}^{*}$ product was found to connect to the $\mathrm{O}_{2}$ atom to form hydroxyl species with a $\mathrm{H}-\mathrm{O}_{1}$ distance of $0.98 \AA$ As. As shown in Table 2, this step must overcome an energy barrier of $0.73 \mathrm{eV}$, and the reaction was found to be exothermic $(-1.07 \mathrm{eV})$.

\subsection{2. $\mathrm{R2}: \mathrm{CH}_{2} \mathrm{O}^{*}+\mathrm{OH}^{*} \rightarrow \mathrm{CHO}^{*}+\mathrm{H}_{2} \mathrm{O}^{*}$}

The presence of an $\mathrm{OH}^{*}$ species derived from water decomposition [22] appeared to have a dramatic effect in terms of lowering the energy barriers associated with the dehydrogenation reactions. With the assistance of the hydroxyl species, the dehydrogenation of $\mathrm{CH}_{2} \mathrm{O}^{*}$ was found to be much more facile than R1 with the energy barrier determined to be as low as $0.15 \mathrm{eV}$. In addition, the exothermicity of this reaction was reduced significantly from -1.07 (R1) to $-2.67 \mathrm{eV}$, indicating that this reaction is much more thermodynamically favored. In the initial state, $\mathrm{CH}_{2} \mathrm{O}^{*}$ and $\mathrm{OH}^{*}$ were coadsorbed on two different surface rows. The distance $(\mathrm{H}-\mathrm{O})$ between the dissociated $\mathrm{H}$ atom of $\mathrm{CH}_{2} \mathrm{O}^{*}$ and the $\mathrm{O}$ atom of the hydroxyl $\mathrm{OH}^{*}$ was about $3.48 \AA$ in the reactant, which was subsequently reduced to 1.88 $\AA$ in the transition state. In addition, the breaking $\mathrm{C}-\mathrm{H}$ bond length was calculated to be $1.17 \AA$. Following the dissociation, the water produced was located on the top of $\operatorname{In}_{3}$ atom with an O- $\operatorname{In}_{3}$ distance of $2.38 \AA$ and its hydrogen atom pointing towards the nearby lattice $\mathrm{O}_{2}$ atom. In a similar manner to the R2 reaction, the $\mathrm{CHO}^{*}$ product was adsorbed at the $\mathrm{In}_{1}-\mathrm{O}_{1}$ bridge site.

\subsection{3. $\mathrm{R3:} \mathrm{CHO}^{*} \rightarrow \mathrm{CO}^{*}+\mathrm{H}^{*}$}

The $\mathrm{CHO}^{*}$ species can be further dehydrogenated to $\mathrm{CO}^{*}$. As shown in Fig. 3, the reactant $\mathrm{CHO}^{*}$ is positioned at the $\mathrm{In}_{1}-\mathrm{O}_{1}$ bridge site, with $\mathrm{C}-\mathrm{O}, \mathrm{C}-\mathrm{O}_{1}$, and $\mathrm{O}-\mathrm{In}_{1}$ distances of $1.27,1.28$, and $2.22 \AA$, respectively. During the transition state, the $\mathrm{C}-\mathrm{H}$ bond length increased from its initial value of 1.10 to $1.47 \AA$, and the $\mathrm{H}_{-} \mathrm{O}_{3}$ distance was found to be $1.32 \AA$. In addition, the 0 atom of the $\mathrm{CHO}^{*}$ species effectively broke loose of the restrictions of the lattice $\mathrm{In}_{1}$ atom, as shown in Fig. 2. The $\mathrm{O}-\mathrm{C}-\mathrm{H}$, $\mathrm{O} 1-\mathrm{C}-\mathrm{O}, \mathrm{O}_{1}-\mathrm{C}-\mathrm{H}$, and $\mathrm{C}-\mathrm{H}-\mathrm{O}_{3}$ bond angles were found to be
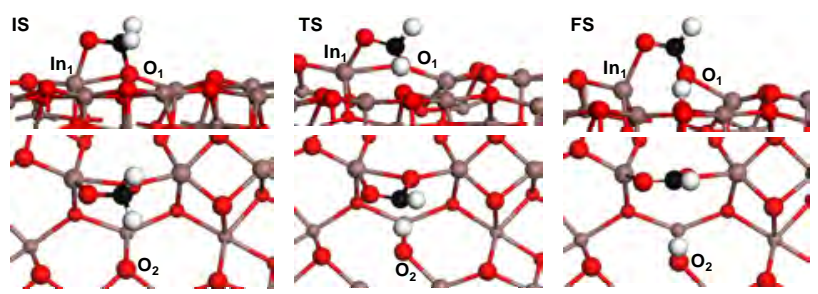

$\mathrm{CH}_{2} \mathrm{O}^{*} \rightarrow \mathrm{CHO}^{*}+\mathrm{H}^{*}$
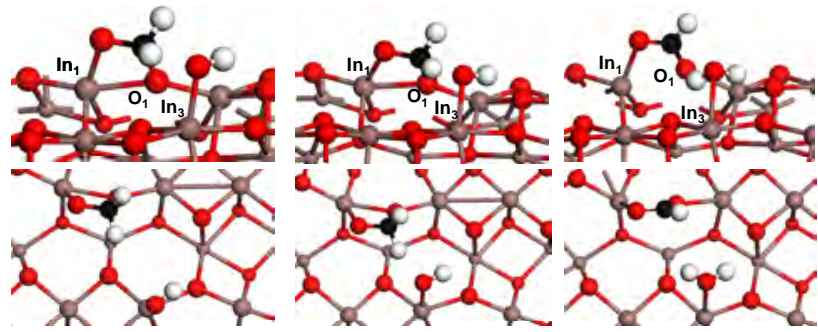

$\mathrm{CH}_{2} \mathrm{O}^{*}+\mathrm{OH}^{*} \rightarrow \mathrm{CHO}^{*}+\mathrm{H}_{2} \mathrm{O}^{*}$
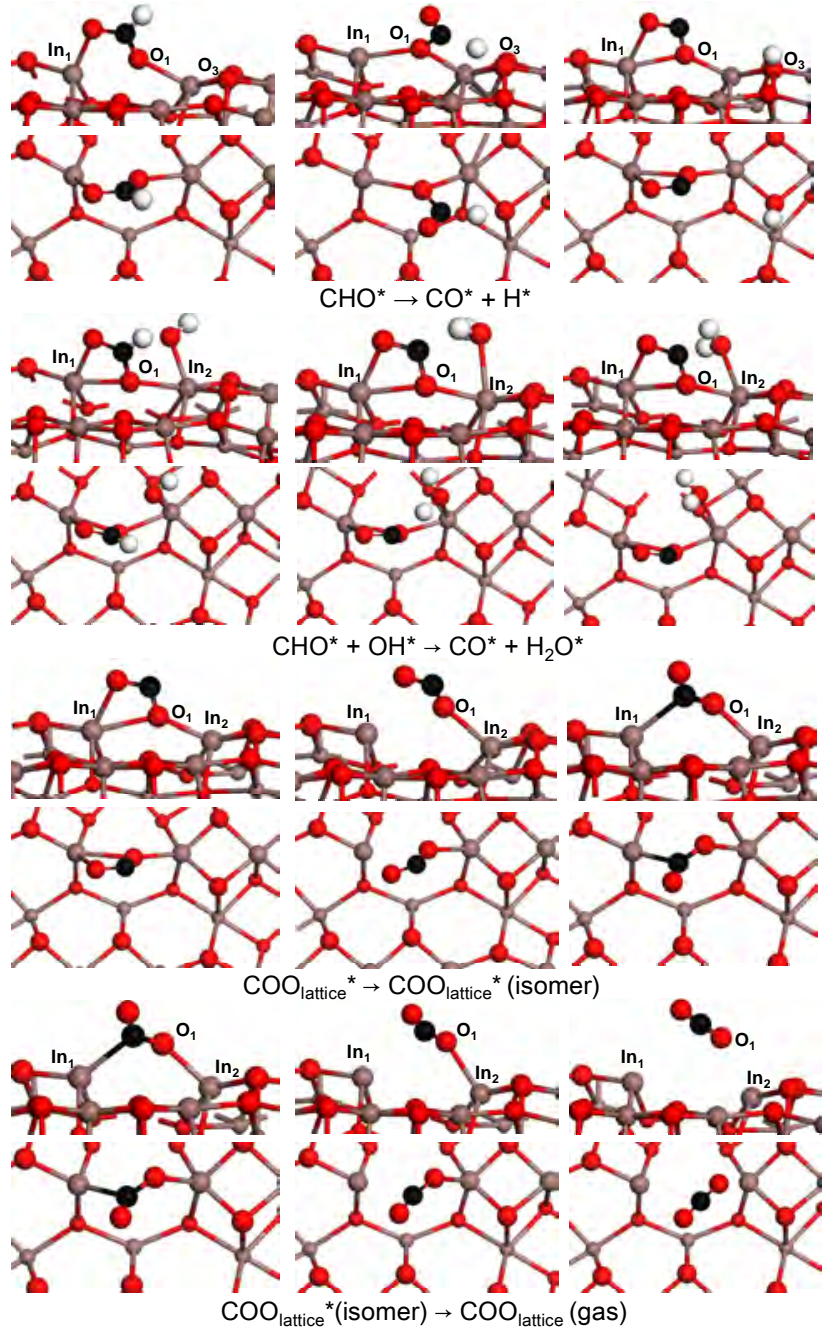

Fig. 3. The atomic structures with side and top views of the initial state (IS), transition state (TS), and final state (FS) for each reaction on $\mathrm{In}_{2} \mathrm{O}_{3}(110)$ listed in Table 2.

$125.09^{\circ}, 123.83^{\circ}, 111.03^{\circ}$, and $160.01^{\circ}$, respectively. In the final product, the $\mathrm{O}$ atom of the $\mathrm{CO}^{*}$ species was recombined with the lattice $\operatorname{In}_{1}$ atom, whereas the $\mathrm{C}$ atom coordinated to the $\mathrm{O}_{1}$ atom. The $\mathrm{In}_{1}-\mathrm{O}, \mathrm{O}-\mathrm{C}$, and $\mathrm{C}-\mathrm{O}_{1}$ distances were $2.30,1.25$, and 
$1.35 \AA$, respectively. In addition, the hydrogen atom produced was located on top of the $\mathrm{O}_{3}$ atom. Compared with the $\mathrm{R} 1$ and R2 reactions, the energy barrier for this step was much higher $(1.91 \mathrm{eV})$, and the reaction became endothermic with a reaction heat of $0.48 \mathrm{eV}$. It is noteworthy that the interaction of $\mathrm{CO}$ with the lattice $\mathrm{O}_{1}$ appeared to form a bended $\mathrm{CO}_{2}$ molecule (COOlattice $^{*}$ ), and this will be discussed in greater detail in reactions $\mathrm{R} 5$ and R6.

\subsection{4. $\mathrm{R} 4: \mathrm{CHO}^{*}+\mathrm{OH}^{*} \rightarrow \mathrm{CO}^{*}+\mathrm{H}_{2} \mathrm{O}^{*}$}

In contrast to reaction $\mathrm{R} 3$, the participation of $\mathrm{OH}^{*}$ significantly reduced the activation energy for the dehydrogenation of $\mathrm{CHO}^{*}$, and the barrier for this step was found to be only 0.58 $\mathrm{eV}$, which is comparable to that of R1. The endothermicity of this reaction was equal to $0.43 \mathrm{eV}$. As shown in Fig. 4, this reaction was determined to be the rate-determining step. The coadsorption of $\mathrm{CHO}^{*}$ and $\mathrm{OH}^{*}$ leads to the initial state. The surface $\mathrm{OH}^{*}$ sits on top of the $\mathrm{In}_{2}$ atom with a distance $(\mathrm{O}-\mathrm{H})$ of $2.44 \AA$ between its $\mathrm{O}$ and the $\mathrm{H}$ atom of $\mathrm{CHO}^{*}$. This distance then changes to become $1.02 \AA$ in the transition state. The $\mathrm{C}-\mathrm{H}$ bond length was calculated to be $1.79 \AA$ A. Following the decomposition, the $\mathrm{CO}^{*}$ and $\mathrm{H}_{2} \mathrm{O}^{*}$ species were located at the $\mathrm{In}_{1}-\mathrm{O}_{1}$ bridge site and on top of the $\mathrm{In}_{2}$ atom, respectively. Recalling that the barrier for the formation of $\mathrm{OH}^{*}$ from the decomposition of $\mathrm{H}_{2} \mathrm{O}^{*}$ is almost $0 \mathrm{eV}$, as calculated in our previous work [22], this is enough for the $\mathrm{OH}^{*}$ to participate in the elementary steps of the $\mathrm{R} 2$ and $\mathrm{R} 4$ reactions.

\subsubsection{R5: $\mathrm{COO}_{\text {lattice }}{ }^{*} \rightarrow \mathrm{COO}_{\text {lattice }}$ (isomer)}

Before desorption from the surface, the $\mathrm{COO}_{\text {lattice* }}{ }^{*}$ species must undergo a process of conversion to a different isomer denoted as $\mathrm{COO}_{\text {lattice }}{ }^{*}$ (isomer). As shown in Table 2, this transformation only requires a low barrier of $0.20 \mathrm{eV}$ with a reaction energy of $-0.51 \mathrm{eV}$. As displayed in Fig. 3, during the transition state, the $\mathrm{O}-\mathrm{In}_{1}$ bond distance was $2.28 \AA$, and the $\mathrm{O}-\mathrm{C}-\mathrm{O}_{1}$ bond angle was computed to be $140.51^{\circ}$. In the final state, the $\mathrm{C}$ atom is connected to the $\mathrm{In}_{1}$ atom, and the $\mathrm{O}$ atom of the $\mathrm{CO}^{*}$ points away from the surface.

\subsubsection{R6: $\mathrm{COO}_{\text {lattice }}$ (isomer) $\rightarrow \mathrm{COO}_{\text {lattice }}$ (gas)}

Once the isomer of the $\mathrm{COO}_{\text {lattice }}{ }^{*}$ species is formed on the surface, it begins to desorb. In this step, the main change involves the scission of the $\mathrm{C}-\operatorname{In}_{1}$ and $\mathrm{O}_{1}-\mathrm{In}_{2}$ bonds. In the transition state, the lengths of these two bonds were found to be 2.99 and $2.35 \AA$, respectively. The $\mathrm{O}-\mathrm{C}-\mathrm{O}_{1}$ angle then undergoes a change from initial value of $134.25^{\circ}$ to $160.78^{\circ}$. In the final state, a linear $\mathrm{CO}_{2}$ gas molecule was weakly adsorbed on the surface. This molecule can be readily cleaned out from the surface. Reaction R6 also possesses a low energy barrier with a value of $0.23 \mathrm{eV}$, and the $\Delta E$ was calculated to be $0.17 \mathrm{eV}$. The combination of reactions R5 and R6 provides a total energy barrier and exothermicity for $\mathrm{CO}_{2}$ generation of 0.20 and -0.34 $\mathrm{eV}$, respectively. Following the reaction, one of the 0 vacancies is yielded. The $\mathrm{OH}^{*}$ species might then transfer to this site to assist in the recovery of the catalyst, although we did not study this process and will be exploring this possibility in greater detail in the future.

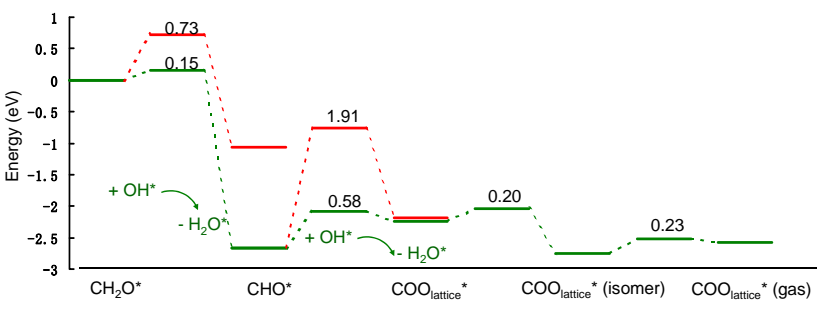

Fig. 4. Potential energy profile for the reaction from $\mathrm{CH}_{2} \mathrm{O}$ to $\mathrm{CO}_{2}$ on $\mathrm{In}_{2} \mathrm{O}_{3}(110)$.

Based on the current calculation results, pure $\mathrm{In}_{2} \mathrm{O}_{3}$ appears to catalyze the MSR process to produce $\mathrm{CO}_{2}$, therefore confirming the experimentally observed selectivity [16]. Although the bimetallic PdIn alloy is often believed to be beneficial for switching from CO-selective methanol dehydrogenation to $\mathrm{CO}_{2}$-selective MSR, there are no confirmed reports in the literature pertaining to the mechanism of this suggested selectivity [21]. To develop a thorough understanding of the whole story of MSR in the context of this system, it is clear that further efforts will be needed to establish the mechanism of the MSR reaction on the PdIn alloy. The well-known synergistic effect between the alloy and the oxide may also influence the reaction. Given that the study of these effects is more involved, work towards developing a greater understanding in this area will have to be reserved for some future work. We believe that insights gained in the current study from studying the reaction networks on this surface will provide a solid platform for the design of new catalysts for the MSR process.

\section{Conclusions}

We have reported a periodic DFT study of the decomposition of formaldehyde to $\mathrm{CO}_{2}$ on an $\mathrm{In}_{2} \mathrm{O}_{3}(110)$ surface. The reaction between the adsorbed formaldehyde and the available hydroxyl generated from water splitting to produce $\mathrm{CHO}$ is much more facile than the direct dehydrogenation of formaldehyd. The CHO was consequently deprived a $\mathrm{H}$ atom by neighboring hydroxyls. Finally, the $\mathrm{CO}$ produced by the process seizes a lattice $\mathrm{O}$ atom to generate $\mathrm{CO}_{2}$, which was readily desorbed from the surface. Our calculation results are consistent with the experimental observations, and will help to provide a better understand the catalytic role of $\mathrm{In}_{2} \mathrm{O}_{3}$ in terms of selectivity during the MSR process.

\section{Acknowledgments}

We thank Professor Daiqian Xie for several useful discussions.

\section{References}

[1] Palo D R, Dagle R A, Holladay J D. Chem Rev, 2007, 107: 3992

[2] Trimm D L, Onsan Z I. Catal Rev-Sci Eng, 2001, 43: 31

[3] Olah G A. Catal Lett, 2004, 93: 1

[4] Sa S, Silva H, Brandao L, Sousa J M, Mendes A. Appl Catal B, 2010, 99: 43 


\section{Graphical Abstract}

Chin. J. Catal., 2013, 34: 1855-1860 doi: 10.1016/S1872-2067(12)60662-7

First-principle insights into the catalytic role of indium oxide in methanol steam reforming

Sen Lin*, Xinxin Ye

Fuzhou University

Our calculation results indicate that $\operatorname{In}_{2} \mathrm{O}_{3}$ plays an important role in terms of the selectivity during methanol steam reforming (MSR), confirming the experimentally observed selectivity towards $\mathrm{CO}_{2}$.

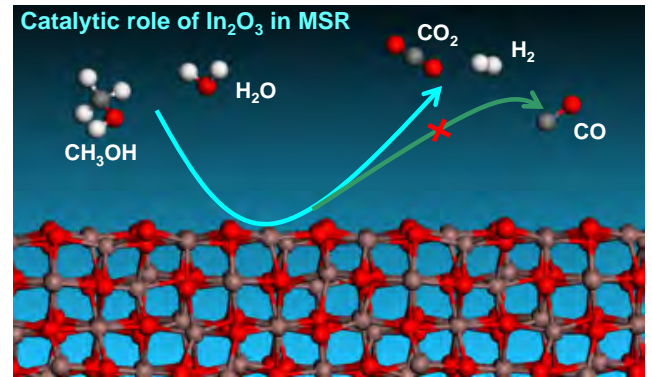

[5] Iwasa N, Mayanagi T, Ogawa N, Sakata K, Takezawa N. Catal Lett, 1998, 54: 119

[6] Iwasa N, Suzuki H, Terashita M, Arai M, Takezawa N. Catal Lett, 2004, 96: 75

[7] Pfeifer P, Kolbl A, Schubert K. Catal Today, 2005, 111: 76

[8] K G X, C D W, Q H C, X L W. Chin J Catal (顾向奎, 丁戊辰, 黄传奇, 李微雪, 催化学报), 2012, 33: 1427

[9] Iwasa N, Takezawa N. Top Catal, 2003, 22: 215

[10] Lin S, Xie D Q, Guo H.J Mol Catal A, 2012, 356: 165

[11] Gu X K, Li W X. J Phys Chem C, 2010, 114: 21539

[12] Lin S, Ma J Y, Zhou L S, Huang C J, Xie D Q, Guo H. J Phys Chem C, 2012, 117: 451

[13] Lin S, Xie D Q, Guo H.J Phys Chem C, 2011, 115: 20583

[14] Lin S, Johnson R S, Smith G K, Xie D Q, Guo H. Phys Chem Chem Phys, 2011, 13: 9622

[15] Smith G K, Lin S, Lai W Z, Datye A, Xie D Q, Guo H. Surf Sci, 2011, 605: 750

[16] Lorenz H, Jochum W, Klotzer B, Stoger-Pollach M, Schwarz S, Pfaller K, Penner S. Appl Catal A, 2008, 347: 34

[17] Lorenz H, Friedrich M, Armbruster M, Klotzer B, Penner S. J Catal, 2013, 297: 151

[18] Halevi B, Lin S, Roy A, Zhang H, Jeroro E, Vohs J, Wang Y, Guo H,
Datye A K. J Phys Chem C, 2013, 117: 6493

[19] Bielz T, Lorenz H, Amann P, Klotzer B, Penner S. J Phys Chem $C$, 2011, 115: 6622

[20] Rameshan C, Lorenz H, Mayr L, Penner S, Zemlyanov D, Arrigo R, Haevecker M, Blume R, Knop-Gericke A, Schlogl R, Klotzer B. J Catal, 2012, 295: 186

[21] Ye J Y, Liu C J, Ge Q F. Phys Chem Chem Phys, 2012, 14: 16660

[22] Lin S, Xie D Q. Chin J Chem, 2012, 30: 2036

[23] Walsh A, Catlow C R A.J Mater Chem, 2010, 20: 10438

[24] Liu S B, Li J Q, Zhang Y F, Xu X L, Chen Z H. J Mol Struc: Theochem, 2008, 866: 75

[25] Sun H G, Fan W L, Li Y L, Cheng X F, Li P, Zhao X. J Phys Chem C, 2010, 114: 3028

[26] Ye J Y, Liu C J, Ge Q F. J Phys Chem C, 2012, 116: 7817

[27] Kresse G, Furthmüller J. Phys Rev B, 1996, 54: 11169

[28] Kresse G, Furthmüller J. Comput Mater Sci, 1996, 6: 15

[29] Kresse G, Hafner J. Phys Rev B, 1993, 47: 558

[30] Perdew J P, Chevary J A, Vosko S H, Jackson K A, Pederson M R, Singh D J, Fiolhais C. Phys Rev B, 1992, 46: 6671

[31] Blöchl P E. Phys Rev B, 1994, 50: 17953

[32] Kresse G, Joubert D. Phys Rev B, 1999, 59: 1758

[33] Henkelman G, Jonsson H. J Chem Phys, 2000, 113: 9978

\section{利用第一性原理研究氧化铟在甲醇水蒸气重整反应中的催化作用

\author{
林 森, 叶欣欣
} \\ 福州大学光催化研究所, 福建省光催化重点实验室, 国家重点实验室培育基地, 福建福州350002}

摘要: 基于第一性原理方法, 证明了甲醛在 $\mathrm{In}_{2} \mathrm{O}_{3}(110)$ 表面可以选择性地转化为 $\mathrm{CO}_{2}$. 水分解得到的OH物种有利于甲醛脱氢得到 $\mathrm{CHO}$, 后者不易直接脱氢, 其 $\mathrm{H}$ 原子被周围的 $\mathrm{OH}$ 捕获生成 $\mathrm{CO}$ 和 $\mathrm{H}_{2} \mathrm{O}$. 最后, 相比较其从表面直接脱附, $\mathrm{CO}$ 更容易获得一个晶格氧 生成 $\mathrm{CO}_{2}$. 计算结果表明, 在没有PdIn合金参与催化的甲醇水蒸气重整反应过程中, $\mathrm{In}_{2} \mathrm{O}_{3}$ 确实扮演着非常重要的角色, 进而从理论 上证实了甲醇在氧化铟表面选择性生成 $\mathrm{CO}_{2}$ 的实验结果.

关键词: 密度泛函理论; 甲醇水蒸气重整; 反应机理; 氧化铟

收稿日期: 2013-06-04. 接受日期: 2013-07-10. 出版日期: 2013-10-20.

*通讯联系人.电话：(0591)83969175; 传真：(0591)83779105; 电子信箱：slin@fzu.edu.cn

基金来源：国家自然科学基金(21203026); 福建省自然科学基金(2012J05022); 高等学校博士学科点专项科研基金 (20123514120001).

本文的英文电子版由Elsevier出版社在ScienceDirect上出版(http://www.sciencedirect.com/science/journal/18722067). 